\title{
ANALYSIS OF THE ECONOMIC VIABILITY OF THE INSTALLATION OF A PHOTOVOLTAIC SYSTEM AT JORGE DE ABREU REGIONAL HOSPITAL IN SINOP-MT
}

\author{
Matheus Holzbach ${ }^{* 1}$, Carla Carol Silva e Carvalho ${ }^{1}$, Adriana Sousa Rezende ${ }^{1}$ \\ ${ }^{1}$ Faculty of Exact and Technological Sciences, University of Mato Grosso State, Sinop, Brazil \\ e-mail: matheus.holzbach@unemat.br
}

\section{ABSTRACT}

Brazilian consumers have the possibility to produce their own energy using renewable sources or qualified cogeneration and even provide the surplus for the distribution network of their locality, as determined by Normative Resolution no. 482/2012 issued by the National Electric Energy Agency (ANEEL). In view of this, the use of photovoltaic systems for electricity generation has grown surprisingly reaching the mark of 8 gigawatts of installed power on Brazilian soil in the year 2021 [1]. In Brazil, public agencies represent 0.1\% with 4.7MW installed [1], and 0.38\% in the state of Mato Grosso [14]. Thus, aiming at the rise of electricity generation in public buildings due to the possibility of reducing the electric bill costs, the present work deals with the dimensioning, budget quotation and economic feasibility analysis regarding the installation of a grid-connected photovoltaic power generation system to meet the energy demands of Jorge de Abreu Regional Hospital in the city of Sinop, Mato Grosso state, Brazil. After carrying out the necessary research based on the techniques present in the economic sciences, as Minimum Attractiveness Rate (MRA), Net Present Value (NPV), Internal Rate of Return (IRR) and calculation of Payback, the present work considered a grid-connected solar energy generation system of $585 \mathrm{~kW}$ to supply the hospital's average monthly consumption of $93.829 \mathrm{kWh} / \mathrm{month}$. The investment analysis showed that the project for the implementation of the photovoltaic system will have its NPV viable as of the 4th year of installation and the Payback (return on investment), observing the monetary corrections, of approximately four years and five months, thus configuring the system as economic financially.

Index terms: Distributed generation, economic indicators, photovoltaic energy, renewable sources, sustainability.

\section{INTRODUCTION}

Renewable energy sources are emerging technologies on the current world stage that have become a sustainable alternative for the production of electricity. It is estimated that renewable energies already occupy about $83 \%$ of the Brazilian energy matrix, according to the speech of the Secretary of Energy Planning and Development of the Ministry of Mines and Energy, Reive Barros [10]. Although energy sources that use fossil resources, such as oil, have large stocks, they are not renewable yet, not to mention the significant degradation of the environment they cause. Due to this, the sources with unlimited resources have been gaining prominence in the market, because in extension to the guarantee of not being resources that will be exhausted in nature, they are still relatively clean, decreasing the negative impacts to the environment.

One of the most widespread examples today is photovoltaic energy, which through a system of capturing solar rays through photovoltaic cells, is able to convert the irradiation collected into electric current by means of the so-called photovoltaic effect, thus supplying energy to the consumer unit in which it was installed. In this type of system, the energy produced can be connected to the network, configuring the system as ON-GRID, or it can be stored in stationary batteries, configuring the system as OFFGRID [20]. In the system connected to the network, the conceived energy is lowered in the energy account and the surplus generation is converted into credits for the consumer, and can be used in up to 60 months, in an agreement with the contracted concessionaire, this is known as the system of "Solar Energy Credits" regulated by ANEEL (National Electric Energy Agency), for captive consumers who install this specie of system.

For the analysis of the viability of the installation of a photovoltaic system it was obtained as a basis researches in the municipality of Sinop, observing the enormous potential of the territory considering the incidence of solar rays which have an average of 5.00 $\mathrm{kWh} / \mathrm{m}^{2}$. day [7]. In this perspective, through review of previous works regarding solar energy in the city, it was also noted that the presence of photovoltaic systems is growing every day, however, only in the year 2019 there was a growth of $84 \%$ of all the facilities 
of the locality, not to mention the significant increase of $514,35 \%$ compared to the year 2018 , thus making the market quite diversified and accessible [14].

Based on the aforementioned factors this structure was implemented in a public institution, namely the Jorge de Abreu Regional Hospital, which was inaugurated in December 2014 and is a reference for health in the region, serving as shelter for more than 430,000 people and having a large unit with care for several clinical sectors [11]. In this way, by reason of the large expenses that the hospital has to bear, the alternative of generating its own energy is an attractive option in terms of the reduction of expenses, since solar energy has an investment that returns after a certain period and that in this case, would return in a short time if compared to the years of operation of the entity.

Based on this assumption, the main objective is to analyze the feasibility of implementing a photovoltaic system in this building, the Jorge de Abreu de Sinop Regional Hospital, considering aspects such as the cost of projects, equipment and installation. In addition, there will be the use of definitions of economic studies such as NPV (Net Present Value), IRR (Internal Rate of Return) and Payback to prove the importance of the installation of the system.

been adopted which are listed in the subsequent sections, including the formulas presented, all taken from the digital practical guide "Financial Indicators for Investment Analysis" by author Renata Freitas de Camargo [4].

1) Minimum Attractiveness Rate: The acronym MRA, the minimum attractiveness rate, is a percentage that corresponds to the minimum that an investor proposes to earn, or the maximum that someone proposes to pay when making a loan. It is considered an excellent tool especially when choosing among the various investment options available. At both strategic and financial levels, MRA is one of the first tools to assess the attractiveness of an investment.

The investment analysis of MRA is estimated on the basis of the main interest rates practiced by the market, the researchers can mention for example those that currently have the most impact:

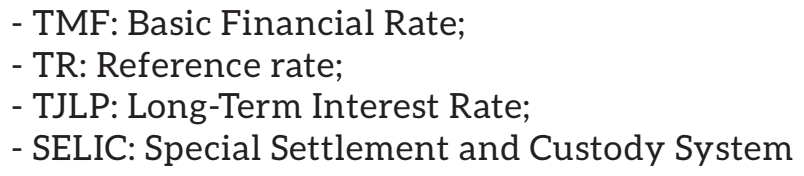

2) Net Present Value: Net Present Value (NPV) is an internationally accepted method by finance professionals and widely used to plan long-term investments as it is one of the best-known methods when dealing with analysis of the viability of investment projects [4]. The method consists of bringing to zero date all the cash flows of an investment project and adding them to the value of the initial investment, using as discount rate the Minimum Attractiveness Rate (MRA) of the company or project.

With the calculation of the Net Present Value, it is possible to make adjustments, discounting the interest rates to get the true notion of the value of money in the future. For this reason, the NPV not only compares 
the investment with the expected return, but also takes into account the capital appreciation over time by calculating the real investment gain. The NPV formula is expressed as follows:

$$
V_{P L}=\sum_{t=1}^{N} \frac{F c_{t}}{(1+i)^{n}}
$$

where, NPV is the Net Present Value, FC is the Cash Flow, $\mathrm{t}$ is the time when the cash flow occurred, $\mathrm{i}$ is the discount rate (or minimum attractiveness rate) and $\mathrm{n}=$ Time period .

For the analysis of the result obtained by calculating the NPV there are three possible situations:

- negative NPV: expenditure greater than revenue, that is, the project is unviable;

- positive NPV: revenue greater than expenditure, that is, the project is viable;

- NPV Zero = Income and expenditure are equal, that is, the decision to invest in the project is neutral.

3) Internal Rate of Return: The Internal Rate of Return also known as the IRR, is the rate that will equal the anticipated cash flow to the value of the investment. This rate is nothing more than an indicator, greatly used to assess the attractiveness of a project or investment. Its calculation is given by the formula described below:

\section{METHODOLOGY}

This work addresses the analysis of the financial viability of the investment aiming at the installation of a photovoltaic power generation system to meet the consumption needs of the Regional Hospital of Sinop - MT. In a first moment the researchers will deal with the dimensioning of the photovoltaic system, the researchers will calculate the variables that directly impact the generation and they will carry out the quotation of the equipment, project and labor costs. After that, the researchers will perform the investment analysis to evaluate its implementation.

The two consumer units that serve the Jorge de Abreu de Sinop Regional Hospital were considered; the first one located at number 2799, avenue of Itaúbas, called Emergency Room, and the second unit located in Street of Caviúnas, without number, center, called Regional Hospital. Both units are three-phase, served on average voltage with a $127 / 220 \mathrm{~V}$ secondary voltage lowering transformer and belonging to tariff group A.

For the preparation of this study, it is worth noting that some analyses could not be performed due to the location of the equipment installation not having been decided. In this sense, it is worth emphasizing

$$
V P=\text { capital }+\sum_{t=1}^{N}{\frac{F_{t}}{(1+i)^{t}}}^{02}
$$

where, VP is the present value, Capital is the investment value, $\mathrm{N}$ is the Amount of periods, $\mathrm{Ft}$ is the Capital Inflow in period $t$ and $i$ is the Internal rate of return.

When the researchers analyze the IRR, they should compare it with the minimum attractiveness rate (MRA), because if its percentage is lower, the investment is economically unviable. Already if the IRR is larger than the MRA, the investment is considered viable.

4) Payback: The recovery time of the investment, or popularly known as Payback, is another risk indicator, being an important indicator within the investment decision-making process. It represents the number of periods necessary for the flow of benefits to exceed the invested capital.

Although it is a simple calculation, it is essential that all variables linked to the cash flow are analyzed for a correct execution of the Payback calculation, since the entered values and the discounted expenses must faithfully represent the planned scenario, so that it does not present unwanted surprises.

that the resistance of the roof for the installation of the panels was not verified, the study of the coverage that allows the analysis of the interference of the shading throughout the year in the place of accommodation of the modules was not contemplated, and the calculations of losses by the voltage drop and heating of the inverter could not be calculated. For the purposes of carrying out the work, the researchers estimate, in comparison with other systems installed in the city of Sinop-MT, that the total losses of the solar energy plant will not exceed $10 \%$, assuming a general efficiency of the system of $90 \%$. Thus, the calculations presented should be reviewed and adjusted when the definition of points is solved and due technical studies are carried out.

\section{A. Energy Consumption of the Jorge de Abreu de Sinop-MT Regional Hospital}

Determining the consumer's energy consumption is fundamental to the design of the photovoltaic solar system. The consumption considered is the arithmetic average contained in the electric energy bills provided by the head of the financial department of the Jorge de Abreu Regional Hospital of the city of Sinop, Mato 
Grosso. The analyzed period comprises from January to December 2020 and the mean value obtained was 93,829 kWh/month.

Consumption throughout the year showed oscillations mainly in the months of February to July in relation to the months of August to January. For this purpose, the standard deviation of consumption of $28.340 \mathrm{kWh} /$ month was determined in relation to the period observed. Given that the volume of energy demanded may vary according to the number of patients in need of services and the increased use of air conditioners in the excessive heat months of the region, it is not possible to present a linear consumption condition, justifying such a variation.

\section{B. Dimensioning of the Photovoltaic System}

The consumers of group A have hourly charges, that is, at certain hours the researchers call peak hours, when the electric system acts with greater intensity due to the high demand of industries and large trades, the cost of $\mathrm{kWh}$ consumed is higher. With a view on this, the researchers considered the methodology presented by Kikomoto [15] present in equations 3, 4 and 5, where they prioritize the reduction of the monthly demand for electric energy in the same period (end-to-end). If there are leftovers, this balance will be used to reduce consumption in the other tariff post, provided that it is conditioned to a correction of the value attributed by the adjustment factor, according to the formula below:

$$
F A=\frac{T P}{T F P}
$$

where, FA is the adjustment factor, TP is the fare on the end and TFP is the off-edge fare.

Therefore, the generation required is calculated in order to meet the need for injected energy for peak and off-peak periods, using the adjustment factor:

$$
G N=C M F P+(F A * C M P)
$$

where, GN is the generation needed, CMFP is the average off-peak consumption and CMP is the average consumption at the end.

From the solar radiation data of the region and the definition of the photovoltaic module, the researchers can determine with its characteristics the number of modules needed to generate customer consumption. Equation 5 shows as follows:

$$
M N=\frac{G N}{I S \times A M \times E M \times E S \times D E}
$$

where, IS is the average solar irradiation of the region, AM is the contact area of the photovoltaic module, EM is the percentage of efficiency of the photovoltaic module, ES is the efficiency of the generation system and DE the number of sunny days in the year.

In this way the system dimensioned to supply the energetic demands of the hospital requires a system composed of approximately 1,858 photovoltaic modules, resulting in a solar plant of $817.52 \mathrm{kWp}$ of power generation. The budget quotation for the one that meets such needs was carried out next to the main supplier of equipment of this branch, according to the study of the company Greener, and the labor was quoted in the local trade. The final cost of the equipment is $R \$ 2,057,924.00$ and labor of $R \$$ $899,859.44$. Totaling the amount of $\mathrm{R} \$ 2,957,823.44$.

It should also be noted that the quotation considered that the system will be installed on the roof of the building with fixing structures for trapezoidal metal tiles. The cost of adapting the current electrical infrastructure was not included in this study, because it would be necessary to have the prior definition of the places of installation of the equipment by the interested party.

\section{Specification of the Equipment Considered}

The present study took into consideration the system with the best cost that attended the dimensioning, conferred by the technical professional of the responsible area for the company where the quotation of the labor costs was accomplished, being indicated the set of equipments of $585 \mathrm{~kW}$ of power of invertors and $817,52 \mathrm{kWp}$ of power of the photovoltaic modules, composed by:

- 7 three-phase solar photovoltaic inverters of the Growatt brand of nominal power of $75 \mathrm{~kW}$, model MAX75KTL3-LV, output voltage AC 220/380V, with 7 independent MPPTs and maximum DC input power of $112500 \mathrm{~W}$ and efficiency of $98.3 \%$;

- 1 three-phase solar photovoltaic inverter from Growatt, 60kW nominal power, model MAC60KTL3LV, 220/380V AC output voltage, with 3 independent MPPTs and maximum DC input power of $90000 \mathrm{~W}$ and efficiency of $98.5 \%$;

- 1858 monocrystalline photovoltaic modules from Jinko brand composed by 120 cells, model JKM440M60HL4-V, with maximum power of $440 \mathrm{~W}$ and efficiency of $20.39 \%$.

- 3000 meters of Nexans 40023 Energyflex Afitox 0.6/1KV 1500V DC solar cable black.

- 3000 meters of Nexans 40023 Energyflex Afitox 0,6/1KV 1500V DC red solar cable.

- 240 Staubli MC4 Connector 320016P0001-UR PVKBT4/6II-UR female coupler.

- 240 Staubli MC4 Connector 320016P0001-UR PV- 
KBT4/6II-UR male coupler.

- 465 Solar structures Solar Romagnole 4120122 pairs aluminium profile $240 \mathrm{CM} 4$ modules T. metalic trapezoidal.

\section{Maintenance Expenditures and Reduction in System Efficiency}

According to Galdino [9], over the course of its system life some preventive maintenance is necessary to maintain the proper functioning of the system, this maintenance varies annually between 0.5 and $1 \%$ of the initial value of the structure. For the study of this research, the value of $1 \%$ was used.

The efficiency of photovoltaic modules varies according to their lifetime, this reduction in system performance varies between $0.5 \%$ and $1 \%$ per year
[18]. The supplier brings together the technical data sheet of the product that its performance degradation is $2 \%$ in the first year and a linear decrease of $0.55 \%$ for the next 25 years.

\section{E. Annual Average Readjustment Index of the Cost of Electricity}

The adjustment of the annual electricity tariff is made according to the variation of the cost of purchasing energy, transport cost by high voltage lines, social charges, market inflation, operating costs and losses. Based on the data provided by the National Electric Energy Agency, the average readjustment in the last five years of the cost per $\mathrm{kWh}$ consumed in the State of Mato Grosso was approximately $8.32 \%$, which the researchers will use in this work.

\section{RESULTS}

According to the climatic data of the region, made available by CRESESB [7] the researchers can estimate the energy generated by the photovoltaic system and also taking into account the expenditures for maintenance, efficiency of panels and average annual readjustment of energy, and consequently the savings generated by this system.

An important factor to be observed in this case is that the consumer units of the Sinop Regional Hospital have contracted demand for electricity. When the power of the photovoltaic inverters is increased, this contract must be modified, since the sum of the nominal power of the inverters will be higher than the current one.

The tariff paid today by kWh hired by the consumer is $\mathrm{R} \$ 19,26$, and this value is affected by the annual average readjustment of the cost of electricity. The sum of the nominal power of the inverters is $585 \mathrm{~kW}$. Taking into account all the factors addressed in this research, according to Table I, the researchers can analyze the generation and savings forecast generated (without monetary correction) by the system over the first 5 years.

TABLE I

GENERATION FORECAST AND SAVINGS GENERAYED BY THE SYSTEM OVER THE INITIAL FIVE YEARS

\begin{tabular}{|c|c|c|c|c|c|}
\hline Variables/Year & $1^{\text {st }}$ year & $2^{\text {nd }}$ year & $3^{\text {rd }}$ year & $4^{\text {th }}$ year & $5^{\text {th }}$ year \\
\hline Performance of Panels (\%) & $100 \%$ & $98 \%$ & $97,5 \%$ & $96,9 \%$ & $96,4 \%$ \\
\hline Annual Solar Generation (kWh/Year) & 1.126.010,17 & $1.103 .489,97$ & 1.197.296,91 & $1.091 .103,86$ & $1.084 .910,80$ \\
\hline Average Energy Readjustment (\%) & $8,32 \%$ & $8,32 \%$ & $8,32 \%$ & $8,32 \%$ & $8,32 \%$ \\
\hline Energy Cost (kWh/R\$) & 0,68 & 0,74 & 0,80 & 0,87 & 0,94 \\
\hline Cost of Maintenance (R\$) & $6.338,60$ & $6.699,36$ & $7.207,12$ & $7.752,99$ & $8.339,81$ \\
\hline Cost of Demand Contracts (R\$) & $135.205,20$ & $146.454,27$ & $158.639,27$ & $171,838,06$ & $186.134,98$ \\
\hline Economy Generated in the Year ( $R \$)$ & $627.521,15$ & $663.236,50$ & $713.504,42$ & $767.545,84$ & $825.640,70$ \\
\hline Accumulated Economy (R\$) & $627.521,15$ & $1.290 .757,64$ & $2.004 .262,06$ & $2.771 .807,90$ & $3.597 .448,60$ \\
\hline
\end{tabular}




\section{A. Analysis of the Economic Viability of the Investment}

1) Minimum Attractiveness Rate: The Central Bank of Brazil (BACEN) [3] is the authority responsible for ensuring financial stability in Brazil, which confers power over the referenced interest rates traded in the country. The researchers will use the savings income index of the year 2020 of $2.11 \%$, disclosed by BACEN, as reference to the minimum rate of attractiveness, becauseboth financial applications are considered low risk.
2) Net Present Value: From the rate defined in the previous item and using Equation 1 defined in this work, the researchers can determine the Net Present Value (VLP) of the financial investment. For this study the researchers considered the first 25 years of operation of the system because the manufacturer only informed the degradation rate for this period. Table II shows the discounted cash flow and its respective NPV for each year considered.

TABLE II

DISCOUNTED CASH FLOW AND CALCULATED NPV FOR EACH YEAR

\begin{tabular}{|c|c|c|}
\hline $\begin{array}{c}\text { Year } \\
\text { 1st year }\end{array}$ & $\begin{array}{c}\text { Discounted Cash Flow Year (R\$) } \\
614.554,06 \\
\end{array}$ & $\begin{array}{c}\text { Net Gift Value (R\$) } \\
-2.343 .269,38 \\
\end{array}$ \\
\hline 2nd year & $636.109,47$ & $-1.707 .159,91$ \\
\hline 3 rd year & $670.180,58$ & $-1.036 .979,33$ \\
\hline 4th year & $706.043,10$ & $-330.936,23$ \\
\hline 5th year & $743.788,10$ & $412.852,71$ \\
\hline 6th year & $783.514,50$ & 1.196.367,20 \\
\hline 7th year & 825.320 .98 & $2.021 .688,19$ \\
\hline 8th year & $869.314,57$ & $2.891 .002,76$ \\
\hline 9th year & $915.606,66$ & $3.806 .609,42$ \\
\hline 10th year & $964.314,10$ & $4.770 .923,51$ \\
\hline 11th year & $1.015 .559,46$ & $5.786 .482,97$ \\
\hline 12th year & $1.069 .471,29$ & $6.855 .954,26$ \\
\hline 13th year & $1.126 .184,38$ & $7.982 .138,64$ \\
\hline 14th year & $1.185 .840,05$ & $9.167 .978,69$ \\
\hline 15th year & $1.248 .586,45$ & $10.416 .565,14$ \\
\hline 16th year & $1.314 .578,88$ & $11.731 .144,02$ \\
\hline 17th year & $1.383 .980,08$ & 13.115.124,10 \\
\hline 18th year & $1.456 .960,59$ & $14.572 .084,69$ \\
\hline 19th year & $1.533 .699,08$ & $16.105 .783,77$ \\
\hline 20th year & $1.614 .382,71$ & $17.720 .166,48$ \\
\hline 21th year & $1.699 .207,52$ & $19.419 .374,00$ \\
\hline 22th year & $1.788 .378,78$ & $21.207 .752,78$ \\
\hline 23th year & $1.882 .111,49$ & $23.089 .864,22$ \\
\hline 24th year & $1.980 .630,49$ & $25.070 .494,71$ \\
\hline 25th year & $2.084 .171,44$ & $27.154 .666,14$ \\
\hline
\end{tabular}

In addition, in Figure 1, it is possible to observe graphically its performance over the 25 years covered in the study. 


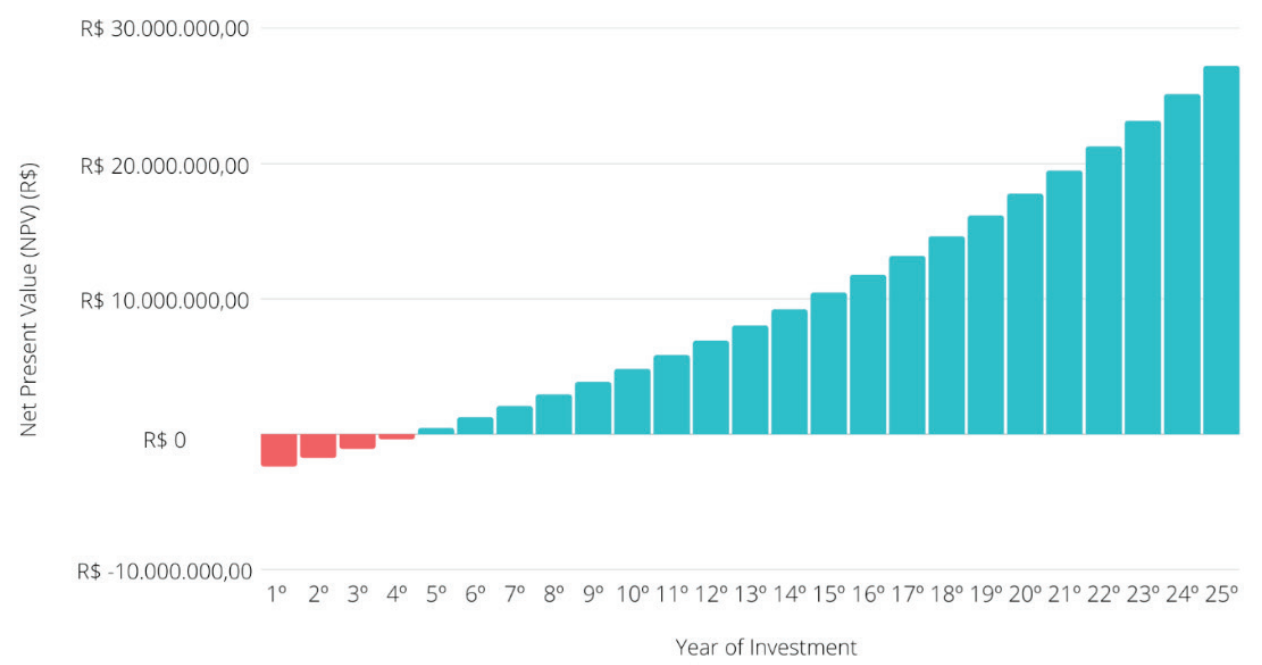

Fig. 1. NPV performance over the observed period.

3) Internal Rate of Return: The internal rate of return (IRR) was calculated for 5, 15 and 25 years of operation in order to perform a comparative. It was obtained respectively: $7 \%$ for the first five years, $27 \%$ for the initial 15 years of operation and $28 \%$ for the total period analyzed.

4) Payback: The Payback of the investment addressed has been calculated on the basis of the forecast cash inflows and discounted cash flow that takes into account the monetary correction of the inflows based on the benchmark rate. For the first case the researchers get the simple Payback of four years and three months. In the second case, the researchers take for analysis the discounted Payback with the value of four years and five months. In Figure 2, the researchers graphically analyze the behavior of Payback discounted over the analyzed period.

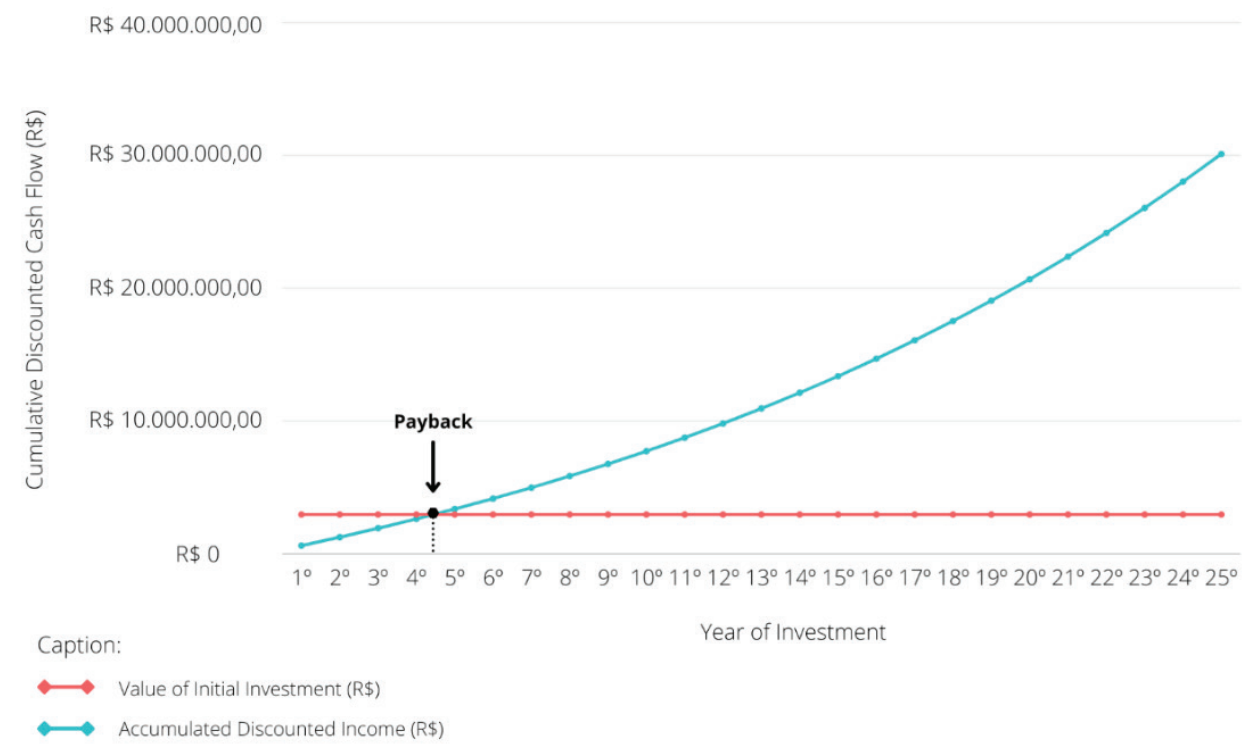

Fig. 2. Payback in relation to the initial investment and discounted cash flow.

\section{DISCUSSION}

Initially, the researchers can observe the high start cost required to install the system estimated at $\mathrm{R} \$ 2,957,823.44$, because of the high consumption present in the energy bills considered. However, when observing the expected calculation of generation and economy provided by the system, the impact is noted as the years evolve.
In the proposed financial viability analysis, by taking into account the Net Present Value (NPV), it can be seen that the investment has an unworkable return on investment in the first four years and is therefore considered viable. The internal rate of return (IRR), calculated for the three cases described, is analyzed as accessible, 
since all percentages are higher when compared to the minimum attractiveness rate (MRA) of $2.11 \%$. The values of Payback portray the moment when the initial investment is recovered being in approximately four years and five months, that is, the exact moment when the investment will obtain financial return.

\section{CONCLUSION}

Paying attention to the fact that the structure will be installed in a public building of social character and will be active for several years, it is understood that the installation of such a photovoltaic power generation system is viable and that in the long term its generated economy will make it possible to invest in other needs of the hospital, such as the acquisition of equipment and the opening of new medical treatment beds for the population.

The analyses carried out and the results obtained are based on the laws in force in the current Brazilian energy scenario, and any additional taxation will directly impact the data calculated for this study. One should also observe the dollar value ( $R \$ 5.58$ quotation of March 2021), because the equipment of a photovoltaic power generation system is imported and negotiated according to the import and export guidelines.

Moreover, it is left as a research suggestion, the technical analysis and implementation study of this system within the structural limitations of the Hospital Regional Jorge de Abreu, exploring the existing electrical installations, available area for installation of the panels and structural report, being possible as a result of this, to calculate in fact the losses by shading, voltage drop in the cabling and heating of the system.

Furthermore, other research can be carried out employing different methodologies to compare or complement the data obtained in this article, such as the levelized cost of energy (LCOE) which allows one to determine if one should go ahead with the project or as a means of comparing different strategies, and can be used for example to analyze the location of the installation of the photovoltaic modules on ground or roof structures.

\section{ACKNOWLEDGEMENTS}

The researchers really appreciate the Mato Grosso Research Foundation for their support and encouragement in carrying out this research and the Secretary of State for Health of Mato Grosso for providing the necessary data.

\section{REFERENCES}

[1] Brazilian Photovoltaic Solar Energy Association, "Brazil exceeds $5 \mathrm{GW}$ mark in photovoltaic capacity", 2021, available: https://www.absolar. org.br/noticia/energia-solar-fotovoltaicasupera-8-gw-e-traz-r-40-bi-de-investimentosao-brasil [May 01, 2021].

[2] M.O.L. Alves, Solar Energy: Study of Electric Energy Generation through OnGrid and Off-Grid Photovoltaic Systems, Dissertation, ICEA, UFOP, Ouro Preto, BR, 2019. available: https://200.239.128.125/ bitstream/35400000/2019/6/MONOGRAFIA_ EnergiaSolarEstudo.pdf [May 07, 2021].

[3] Central Bank of Brazil, "Remuneration of savings deposits",SGS, 2021, available:https://www3.bcb. gov.br/sgspub/localizarseries/localizarSeries. do?method=prepararTelaLocalizarSeries [May 06, 2021].

[4] R.F. Camargo, "Financial indicators for investment analysis", Treasy Investimentos, São Paulo, BR, pp. 4-15, 2017.

[5] R.M.G. Castro, "Renewable energies and decentralised production: Introduction to photovoltaic energy," UTLIST, Lisboa, PT, ed. 0, pp. 1-7, 2002, available: https://www.academia. edu/download/51519880/Introducao_a_ Energia_Fotovoltaica.pdf [May 08, 2021].

[6] J.P. Copetti and M.H. Macagan, "Batteries in photovoltaic solar systems", I CBENS, I Congresso Brasileiro de Energia Solar, ABENS, Associação Brasileira de Energia Solar, Fortaleza, BR, pp. 1-10, 2007.

[7] Reference Center for Solar and Wind Energy Sérgio de S. Brito, "Solar potential - sun data," vol. 3, available: http://www.cresesb.cepel.br/ index.php\#data [May 05, 2021].

[8] E. Brown, "An introduction to solar energy", available: http://www.ccs.neu.edu/home/ feneric/Papers/solar.pdf. [April 05, 2021].

[9] M. A. Galdino, "Historical cost analysis of photovoltaic systems in Brazil", IV CBENS e V CLA da ISES, São Paulo, BR, pp. 44-48, 2012.

[10] Government of Brazil, "Renewable energy sources represent $83 \%$ of the Brazilian electricity matrix," Brasília, BR, 2020, available: https:// www.gov.br/pt-br/noticias/energia-mineraise-combustiveis/2020/01/fontes-de-energiarenovaveis-representam-83-da-matriz-eletricabrasileira [May 14, 2021]. 
[11] Government of Mato Grosso, "Sinop celebrates 46 years with works in infrastructure, health and education," SINFRA, Cuiabá, BR, 2020, available: http://www.sinfra.mt.gov.br//15391191-sinop-comemora-46-anos-comobras-em-infraestrutura-saude-e-educacao [May 14, 2021].

[12] F. Groppi, "Testing of anti-islanding protections for grid-connected inverters," Clean Electrical Power, ICCEP '07, International Conference, Anais, pp. 183-187, 2007.

[13] J.M. Gomez et al., "Solar irradiance: Basic concepts," Revista Brasileira de Ensino de Física, vol. 40, no. 3, e. 3312, São Paulo, BR, 2018, available: https://doi.org/10.1590/1806-9126rbef-2017-0342 [May 14, 2021].

[14] M. Holzbach, A.S. Resende, "Growth of consumer units with photovoltaic generation connected to the electricity grid in the northern region of Mato Grosso," II CONER, UFSCAR, Sorocaba, BR, 2021, available: https://www. coner.com.br/submissao-trabalho/resumo/ NW96U1JpY1l6amhQeEMraFl3N2k5dz09 [May 07, 2021].

[15] B. Kikomoto, "Dimensioning photovoltaic systems for group A", Canal Solar. available: https://canalsolar.com.br/dimensionamentode-sistemas-fotovoltaicos-para-o-grupo-a [May 6, 2021].

[16] L.R. Nascimento, The Long-Term Assessment of a Photovoltaic System Integrated into the Urban Building and Connected to the Public Electricity Grid, M.Sc. Thesis, PPGEC, UFSC, Florianópolis, BR, 2013. available: https://repositorio.ufsc.br/ bitstream/handle/123456789/130919/327988. pdf?sequence=1\&isAllowed=y [May 7, 2021].

[17] G.B. Nunes, M.A. Silva, and A.B.M. Neto, "Use of solar panels and their contribution to preserving the environment," Bolsista de Valor: Petrobras and IF University Project's Divulgation Magazine, 2012, available: https://essentiaeditora.iff.edu.br/index.php/ BolsistaDeValor/article/view/4706 [May 4, 2021]

[18] E.B. Pereira, F.R. Martins, S.L. Abreu, and R. Rüther, Brazilian Atlas of Solar Energy. INPE, São José dos Campos, BR, 2006.

[19] J.T. Pinho, and M.A. Galdino, Engineering Handbook for Photovoltaic Systems. Rio de Janeiro, BR, 2004. available: http://scholar. google.coscholar?hl=en\&btnG=Search\&q=intitle:Manual+de+Engenharia+para+Sistemas+Fotovoltaicos\#0\%5Cnhttp://scholar.google.com/
scholar?hl=en\&btnG=Search\&q=intitle:Manual+de+engenharia+para+sistemas+fotovoltaicos\#0.

[20] R. Rüther, Photovoltaic Solar Buildings. LABSOLAR, UFSC, Florianópolis, BR, 2004.

[21] G.F.W. Soares et al., "Cost comparison between individual photovoltaic systems and mini-photovoltaic plants for rural electrification", III CBENS - III Congresso Brasileiro de Energia Solar, ABENS, Associação Brasileira de Energia Solar, Belém, BR, 2010, available: http://www. cresesb.cepel.br/publicacoes/download/artigo/ III-CBENS/68946.pdf [May 17, 2021].

[22] C.A. Olivati, Photovoltaic Effect and Photoconductivity in Polymeric Devices, M. Sc. Thesis, IFSC, USP, São Carlos, BR, 2000, available: https:// teses.usp.br/teses/disponiveis/76/76132/tde02092010-083031/publico/ClarissadeAlmeidaOlivatiM.pdf [May 18, 2021].

[23] L.K. Tsuruda, T.A. Mendes, L.R. Vitor and M.B. Silveira, "The importance of solar energy for sustainable and social development", 6th International Workshop Avances in Cleaner Production, São Paulo, BR. 2017.comholar?hl=en\&btnG=Search\&q=intitle:Man$\mathrm{ual}+\mathrm{de}+$ Engenharia + para+Sistemas+Fotovoltaicos\#0\%5Cnhttp://scholar.google.com/ scholar?hl=en\&btnG=Search\&q=intitle:Manual+de+engenharia+para+sistemas+fotovoltaicos\#0.

[24] R. Rüther, Photovoltaic Solar Buildings. LABSOLAR, UFSC, Florianópolis, BR, 2004.

[25] G.F.W. Soares et al., "Cost comparison between individual photovoltaic systems and miniphotovoltaic plants for rural electrification", III CBENS - III Congresso Brasileiro de Energia Solar, ABENS, Associação Brasileira de Energia Solar, Belém, BR, 2010, available: http://www. cresesb.cepel.br/publicacoes/download/artigo/ III-CBENS/68946.pdf [May 17, 2021].

[26] C.A. Olivati, Photovoltaic Effect and Photoconductivity in Polymeric Devices, M. Sc. Thesis, IFSC, 